\title{
The regulatory role of DR4 in a spontaneous diabetes DQ8 transgenic model
}

\author{
Li Wen, ${ }^{1}$ Ning-Yuan Chen, ${ }^{1}$ Jie Tang, ${ }^{1}$ Robert Sherwin, ${ }^{1}$ and F. Susan Wong ${ }^{2}$ \\ ${ }^{1}$ Section of Endocrinology, Department of Internal Medicine, Yale University School of Medicine, New Haven, Connecticut \\ ${ }^{2}$ Department of Pathology and Microbiology, University of Bristol, Bristol, United Kingdom
}

Address correspondence to: Li Wen, Section of Endocrinology, Department of Internal Medicine, Yale University School of Medicine, Box 208020, 330 Cedar Street, New Haven, Connecticut 06520, USA. Phone: (203) 785-7186; Fax: (203) 737-5558; E-mail: li.wen@yale.edu.

Received for publication November 3, 2000, and accepted in revised form February 12, 2001.

MHC class II molecules are critical determinants of genetic susceptibility to human type 1 diabetes. In patients, the most common haplotype contains the DRA $1 * 0101-D R B 1 * 0401$ (DR4) and DQA1*0301-DQB1*0302 (DQ8) loci. To assess directly the relative roles of HLA-DQ8 and DR4 for diabetes development in vivo, we generated C57BL/6 transgenic mice that lack endogenous mouse MHC class II molecules but express HLA-DQ8 and/or DR4. Neither HLA-DQ nor HLA-DR transgenic mice developed insulitis or spontaneous diabetes. However, when they were crossed to transgenic mice (C57BL/6) expressing the B7.1 costimulatory molecules on pancreatic $\beta$ cells that do not normally develop diabetes, $\mathrm{T}$ cells from these double transgenic mice were no longer tolerant to islet autoantigens. The majority of DQ8/RIP-B7 mice developed spontaneous diabetes, whereas only $25 \%$ of DR4/RIP-B7 mice did so. Interestingly, when DQ8 and DR4 were coexpressed (DQ8DR4/RIP-B7), only $23 \%$ of these mice developed diabetes, an incidence indistinguishable from the DR4/RIP-B7 mice. T cells from both DR4/RIP-B7 and DQ8DR4/RIP-B7 mice, unlike those from DQ8/RIP-B7 mice, exhibited a Th2-like phenotype. Thus, the expression of DR4 appeared to downregulate DQ8restricted autoreactive T cells in DQ8DR4/RIP-B7 mice. Our data suggest that although both DQ8 and DR 4 can promote spontaneous diabetes in mice with a non-autoimmune-prone genetic background, the diabetogenic effect of the DQ8 allele is much greater, whereas DR4 expression downregulates the diabetogenic effect of DQ8, perhaps by enhancing Th2-like immune responses.

J. Clin. Invest. 107:871-880 (2001).

\section{Introduction}

Type 1 diabetes mellitus (T1DM), also known as insulindependent diabetes mellitus (IDDM), is a polygenic disease, and studies have confirmed that the main locus defining genetic susceptibility is found encoded within the MHC region on human chromosome 6 (1-3). A key function of MHC molecules is to present antigens (Ag's) to $\mathrm{T}$ cells. Specifically, MHC class I molecules present $\mathrm{Ag}^{\prime}$ to $\mathrm{CD}^{+} \mathrm{T}$ cells, whereas MHC class II molecules present Ag's to $\mathrm{CD}^{+} \mathrm{T}$ cells. Evidence derived from the nonobese diabetic (NOD) mouse model of T1DM demonstrating both $\mathrm{CD} 4^{+}$and $\mathrm{CD} 8^{+} \mathrm{T}$ cells are normally required to induce disease (4-7) suggests that the MHC is an important region of genetic susceptibility because of its Ag-presenting function.

$\mathrm{CD}^{+} \mathrm{T}$ cells play an important role in regulating the functions of the immune system, and numerous studies in both human and animals have shown the contribution of Th1 or Th2 to the pathogenesis of a wide variety of diseases. The dichotomy of Th1 and Th2 cells in the development of T1DM has also been well documented (8-15). Most of the studies demonstrate that Th1 cells contribute to the immunopathogenesis of islet $\beta$-cell destruction, whereas Th2 cells mediate disease protection. Based on these studies, new strategies in oral or nasal immunotherapy (which promote Th2 immune responses) for diabetes prevention have been tested in experimental animals (16-19), and some of the regimens are currently in clinical trials. On the other hand, other studies have also shown that Th2 cells have the potential to be diabetogenic, as well (20-22). Thus, like most autoimmune disorders, the pathogenesis of T1DM is very complex. In addition to the role of $\mathrm{CD}^{+} \mathrm{T}$ cells as pathogenic cells, a small subset of $\mathrm{CD}^{+} \mathrm{T}$ cells that are positive for CD25 has been reported recently as regulatory cells that prevent or downregulate the development of autoimmunity $(23,24)$.

The MHC class II loci have been investigated extensively as determinants of genetic susceptibility both in human T1DM and the NOD mouse model. In NOD mice, the predisposing allele is $\mathrm{I}-\mathrm{Ag}^{\mathrm{g}}$, characterized by a substitution of serine for the charged aspartic acid residue at position 57 of the $\beta$ chain. However, the picture is likely to be more complex. For example, many studies suggest that a single residue does not determine susceptibility and that the combination of DQA1 and DQB1 determinants is important (25-28). Whereas a 
number of DQA1-DQB1 pairs are found in Caucasoid populations, the most common haplotype seen in patients with T1DM is the DRA $1{ }^{*} 0101-\mathrm{DRB} 1{ }^{*} 0401$ (DR4)-DQA1*0301-DQB1*0302 (DQ8) haplotype. The predisposing DQ8 allele, the homologue of I-A in the mouse, has a structure similar to I-A ${ }^{87}$.

Transgenic mice that carry only human MHC class II DQ8 molecules and are deficient in murine MHC class II molecules $\left(\mathrm{DQ}^{+} / \mathrm{mII}^{-}\right)$have been generated recently (29-32). However, in studies of diabetes they have been used mainly to identify T-cell determinants of pancreatic $\beta$-cell autoantigens $(29,31,32)$. In no case did these transgenic mice (HLA-DQ8 and/or HLA-DR4) develop diabetes spontaneously, even if they were expressed on the NOD genetic background (32). To investigate whether we could break the tolerance exhibited by the HLA-DQ8 and HLA-DR4 transgenic mice that were not on the NOD genetic background, by providing locally the costimulatory signal B7-1, we introduced this costimulatory molecule using the rat insulin promoter (RIP). The RIP-B7.1 transgene alone normally does not cause diabetes on the C57BL/ 6 genetic background (33). However, we have reported that the expression of DQ8 in which murine MHC class II was knocked out provoked autoimmune diabetes in the majority of non-diabetes-prone RIP-B7.1 C57BL/6 mice (34). In this study we compared the effect of DQ8 with that of DR4, alone or in combination, on disease development. Our goal was to use this "humanized" spontaneous diabetes model system to study the relative immunopathological effect of individual diabetes susceptibility genes in strong linkage disequilibrium. The novel information regarding the role of DR4 in disease development is important for the clinical development of effective immunotherapy, especially because of the fact that DQ8/DR4 HLA genes are commonly found in diabetic patients.

\section{Methods}

Generation of $D R 4^{+} / \mathrm{mII} / \mathrm{RIP}-\mathrm{B} 7.1$ and $D Q 8^{+} D R 4^{+} /$ $m I I^{-} / R I P-B 7.1$ transgenic mice. HLA-DQA $1 * 0301 /$ DQB1*0302 (DQ8) transgenic, murine MHC class II molecule-deficient ( $\left.\mathrm{mII}^{-}\right)$, and RIP-B7.1 C57BL/6 mice were generated as described previously (34). HLA-DRA1*0101/DRB1*0401 (DR4) transgenic mice (B10) were kindly provided by Wicker and Zaller (Merck \& Co. Inc., Rahway, New Jersey, USA) (35). After back-crossing these mice to C57BL/6 genetic background (N4 to N5), we introduced disrupted murine MHC class II molecule ( $\left.\mathrm{mII}^{-}\right)$and B7.1 transgene on pancreatic $\beta$ cells (DR $\left.4^{+} / \mathrm{mII}^{-} / \mathrm{RIP}-\mathrm{B} 7.1\right)$, both on the C57BL/ 6 background. We then intercrossed $\mathrm{DQ}^{+} / \mathrm{mII}^{-} / \mathrm{RIP}-\mathrm{B} 7.1$ mice with DR4 $4^{+} / \mathrm{mII}^{-} / \mathrm{RIP}-\mathrm{B} 7.1$ mice in order to obtain $\mathrm{DQ}^{+}{ }^{+} \mathrm{DR} 4^{+} / \mathrm{mII}^{-} / \mathrm{RIP}-\mathrm{B} 7.1$ mice and all different types of control mice. The expression of the DQ8 and/or DR4 transgene and murine class II I-A $A^{b}$ molecules were screened by flowcytometric analysis of peripheral blood lymphocytes (PBL), and the RIP-B7.1 transgene was screened using
PCR (34). All the mice used in this study were littermates. As mentioned above, all the different types of control mice, such as $\mathrm{DQ}^{+} \mathrm{DR} 4^{+} / \mathrm{mII}^{-} / \mathrm{RIP}^{-B} 7.1^{-}$, $\mathrm{DQ}^{+} / \mathrm{mII}^{-} / \mathrm{RIPB}^{-1} 1^{-}, \mathrm{DR} 4^{+} / \mathrm{mII}^{-} / \mathrm{RIP}^{-B} 7.1^{-}, \mathrm{mII}^{-} / \mathrm{RIP}^{-}$ $\mathrm{B} 7.1^{+}$, and $\mathrm{mII}{ }^{+} / \mathrm{RIP}-\mathrm{B} 7.1^{+}$, were derived from the same pairs for breeding. The possibility that transgenic mice expressed hybrid I-A $\alpha / D Q 8 \beta$ and DR $4 \alpha / \mathrm{I}-\mathrm{E} \beta$ was excluded by negative staining of PBL with $\mathrm{mAb}$ 's specific for I-A $\alpha^{\mathrm{b}}$ (AF6-120.1; PharMingen, San Diego, California, USA) and I-E (Y17; Charlie Janeway), respectively.

To establish the C57BL/ 6 genetic background of the mice used in this study, we also screened the genomic markers in these mice using microsatellite analysis. Seventeen markers were used for the screening: idd 2 to idd 15 (36) and three additional markers (D1Mit232, D1Mit22, and D7Nds6) that were reported to be associated with diabetes in the C57BL/6 genetic background (37).

The mice were housed in specific pathogen-free facilities, and all experiments were undertaken in accordance with approved Yale Animal Care and Use Committee protocols.

Purification of $C D 4^{+} T$ cells. After removing erythrocytes, total splenocytes were incubated with anti-CD8 $\mathrm{mAb}$ (TIB-105; rat IgG2a) on ice for 30 minutes and washed once with cold Click's medium. The cells were then incubated with magnetic beads conjugated with goat anti-mouse IgG/IgM and goat anti-rat IgG (PerSeptive Biosystems, Framingham, Massachusetts, USA) on ice with gentle agitation for 45 minutes. B cells and CD8 cells were removed by using a magnetic plate (PerSeptive Biosystems). The purity of the $\mathrm{CD} 4^{+}$population using this method is routinely over $90 \%$.

Proliferation and cytokine assays. Splenic $\mathrm{T}$ cells $\left(10^{5} /\right.$ well) from diabetic or nondiabetic mice were assayed for antigenic response against three main putative $\beta$-cell autoantigens - GAD (30), insulin (Eli Lilly and Co., Indianapolis, Indiana, USA), and IA-2 (kindly provided by Peter van Endert, Hôpital Necker, Paris, France), as described previously. Secreted cytokine proteins (IL-4, IL-6, IL-10, and IFN- $\gamma$ ) from those responses were measured by ELISA using mAb's and recommended protocols (PharMingen).

Adoptive-transfer experiments. Mice used for these experiments were irradiated (6 Gy) one day before the adoptive transfer. Diabetic splenocytes were injected intravenously into the recipients $\left(10^{7} /\right.$ recipient). All the mice were monitored for glycosuria, and the experiments were terminated 8 weeks after adoptive transfer unless the mice developed diabetes, which was confirmed by blood glucose (>250 mg/dl), and they were sacrificed immediately.

Generation of bone marrow chimera. MII-/RIP-B7.1 mice were used as recipients in the chimeric experiment, and they were irradiated $(8.5 \mathrm{~Gy})$ the day before the bone marrow (BM) reconstitution. Our preliminary BM chimera study showed a high mortality rate in recipients that received over 9 Gy irradiation. This may be due to the fact that the recipients are deficient for 


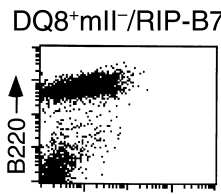

$\mathrm{DQ} \rightarrow$
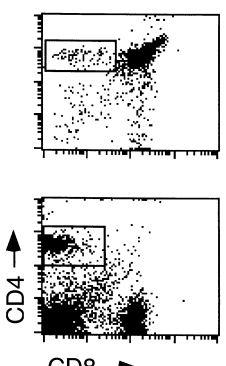

CD8 $\rightarrow$

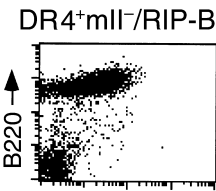

$\mathrm{DR} \rightarrow$
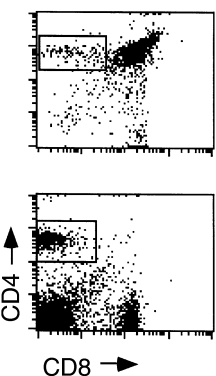

$\mathrm{CD} 8 \rightarrow$

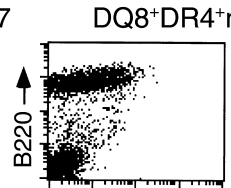

$\mathrm{DQ} \rightarrow$
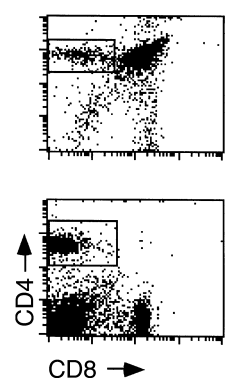

$\mathrm{CD8} \rightarrow$

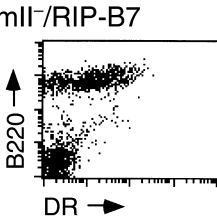

\section{Figure 1}

Expression of HLA transgenes and the selection of CD4 $T$ cells. In the upper panel, lymphocytes isolated from peripheral blood in three types of mice (as indicated) were stained with the B-cell marker B220 (phycoerythrin; $\mathrm{PE}$ ) in combination with either anti-HLA-DQ (FITC) or DR (FITC). In the middle panel, thymocytes were isolated from mice at 5-7 weeks of age and stained with antiCD4 (PE; $y$ axis) and anti-CD8 (FITC; $x$ axis). Gated CD4 single-positive thymocytes were $5.2 \%, 5 \%$, and $9.8 \%$ of total thymocytes analyzed in $\mathrm{DQ}^{+} / \mathrm{mll}^{-} / \mathrm{RIP}-\mathrm{B} 7$, $\mathrm{DR}^{+} / \mathrm{mll}^{-} / \mathrm{RIP}-\mathrm{B} 7$, and $\mathrm{DQ} 8^{+} \mathrm{DR}^{+} / \mathrm{mll}^{-} / \mathrm{RIP}-\mathrm{B} 7$ mice, respectively. In the bottom panel, splenocytes (after removing erythrocytes) were stained with anti-CD4 (PE) and anti-CD8 (FITC). Gated CD4 single-positive splenocytes were $11.4 \%, 11.8 \%$, and $19.5 \%$ of total splenocytes analyzed in $\mathrm{DQ}^{+} / \mathrm{mII}^{-} / \mathrm{RIP}-\mathrm{B} 7, \mathrm{DR}^{+} / \mathrm{mII}^{-} / \mathrm{RIP}-\mathrm{B} 7$, and $\mathrm{DQ}^{+}{ }^{-} \mathrm{R}^{+} / \mathrm{mll}^{-} / \mathrm{RIP}-\mathrm{B} 7$ mice, respectively.
MHC class II and therefore they are immunocompromised. BM cells harvested from nondiabetic $\mathrm{DQ8}^{+} / \mathrm{mII}^{-} / \mathrm{RIP}-\mathrm{B} 7.1, \quad \mathrm{DR} 4^{+} / \mathrm{mII}^{-} / \mathrm{RIP}^{-B} 7.1, \quad$ and $\mathrm{DQ}^{+}{ }^{+} \mathrm{DR}^{+} / \mathrm{mII}^{-} / \mathrm{RIP}-\mathrm{B} 7.1$ donor mice $(8-12$ weeks of age) were injected intravenously into the recipients $\left(10^{7} /\right.$ recipient). All the mice were monitored for glycosuria, and the experiments were terminated 8 weeks after adoptive transfer unless the mice developed diabetes, which was confirmed by blood glucose, and they were sacrificed immediately.

RT-PCR for the detection of expression of chemokine receptors. Purified $\mathrm{CD}^{+} \mathrm{T}$ cells $\left(2 \times 10^{6}\right)$ from $\mathrm{DQ}^{+}{ }^{+} \mathrm{DR}^{+} / \mathrm{mII}^{-} / \mathrm{RIP}-\mathrm{B} 7.1$ and DQ8 ${ }^{+} / \mathrm{mII}^{-} / \mathrm{RIP}-\mathrm{B} 7.1$ mice were activated by anti-CD3 cross-linking ( 24 hours), and total cellular RNA was isolated using Trizol (Life Technologies Inc., Grand Island, New York, USA). The cDNA was synthesized using oligo-dT primer (Amersham Pharmacia Biotech Inc., Piscataway, New Jersey, USA), which recognizes the poly(A) tail of mRNA. PCR was performed using specific primers for mouse CCR5 and CCR2 and same amount of cDNA templates. Standard conditions were used for the PCR, and an internal control, CD3E, was used for normalization of RNA levels.

Ig isotype assay. Blood samples were taken, and sera were separated when experiments were terminated. The levels of Ig isotypes were measured using ELISA, as described previously (38). All the reagents for this assay were purchased from Southern Biotechnology Associates (Birmingham, Alabama, USA).

Immunobistology. Pancreata, kidneys, livers, and salivary glands from all the mice used in this study were examined by immunohistochemistry as described previously (39).

\section{Results}

Expression of DR4-single and DQ8/DR4-double transgenes in mice lacking endogenous mouse MHC class II molecules. We have shown recently that $\mathrm{DQ8}^{+} / \mathrm{mII}^{-} / \mathrm{RIP}-\mathrm{B} 7.1$ C57BL/6 mice develop a high incidence of spontaneous diabetes (34). In the present study we generated $\mathrm{DR}^{+} / \mathrm{mII}^{-}$mice, since the most common haplotype seen in patients with T1DM contains DR4 and DQ8. As shown in Figure 1, the expression of the HLA-DR4 transgene in mice deficient in murine MHC class II molecules partially restored $\mathrm{CD}^{+} \mathrm{T}$ cells to a level similar to that in the $\mathrm{DQ}^{+} / \mathrm{mII}^{-}$transgenic mice. The TCR variable $\beta$ chain $(\mathrm{V} \beta)$ repertoire of the $\mathrm{DR} 4^{+} / \mathrm{mII}^{-}$mice showed no significant differences as compared with wild-type (MHC class II-sufficient) mice (C57BL/6), except that the total number of $\mathrm{CD}^{+}{ }^{+} \mathrm{T}$ cells was lower (approximately $25 \%$ of total $\mathrm{T}$ cells). This was also the case in the $\mathrm{DQ}^{+} / \mathrm{mII}^{-}$mice (30). More $\mathrm{CD}^{+} \mathrm{T}$ cells (about twofold) were selected in mice expressing both DQ8 and DR4 (Figure 1), however, and the coexpression of DQ8 and DR4 did not appear to skew the TCR $\mathrm{V} \beta$ repertoire (data not shown). The expression level of DQ8 and DR4 in DQ8 ${ }^{+} \mathrm{DR} 4^{+} / \mathrm{mII}^{-}$mice was indistinguishable, and neither $\mathrm{DR} 4^{+} / \mathrm{mII}^{-}$nor $\mathrm{DQ} 8^{+} \mathrm{DR} 4^{+} / \mathrm{mII}^{-}$

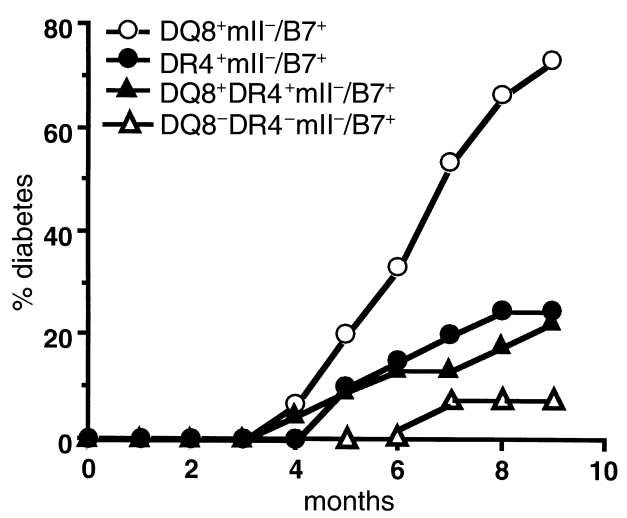

Figure 2

Spontaneous diabetes development in HLA/RIP-B7 transgenic mice. Four groups of mice were used in the study as indicated. Number of mice per group was: $n=15$ ( 7 females and 8 males) for $\mathrm{DQ}^{+} / \mathrm{mll}^{-} / \mathrm{RIP}-\mathrm{B} 7 ; n=20$ (11 females and 9 males) for $\mathrm{DR4}^{+} / \mathrm{mll}^{-} / \mathrm{RIP}-\mathrm{B} 7 ; n=22$ (12 females and 10 males) for $\mathrm{DQ}^{+}{ }^{+} \mathrm{DR} 4^{+} / \mathrm{mII}^{-} / \mathrm{RIP}-\mathrm{B} 7 ; n=10$ (4 females and 6 males) for $\mathrm{mIl}-$ RIP-B7 mice. Mice were housed in specific pathogen-free (SPF) conditions. Diabetes was determined by monitoring of urinary glucose and confirmed by blood glucose $(>250 \mathrm{mg} / \mathrm{dl})$. 
Figure 3

Immunohistochemistry staining of pancreatic sections of diabetic mice, with the diabetic $\mathrm{DQ}^{+} / \mathrm{mll}^{-} / \mathrm{RIP}-\mathrm{B} 7$ mouse in the upper panel, diabetic DR4 $4^{+} / \mathrm{mll}^{-} / \mathrm{RIP}-\mathrm{B} 7$ mouse in the middle panel, and diabetic $\mathrm{DQ}^{+}{ }^{-} \mathrm{DR}^{+} / \mathrm{mll}^{-} / \mathrm{RIP}-\mathrm{B} 7$ mouse in the lower panel. Islet infiltrates were stained for $\mathrm{CD} 4^{+} \mathrm{T}$ cells (left), $\mathrm{CD} 8^{+} \mathrm{T}$ cells (middle), and $\mathrm{B}_{220^{+}} \mathrm{B}$ cells (right).
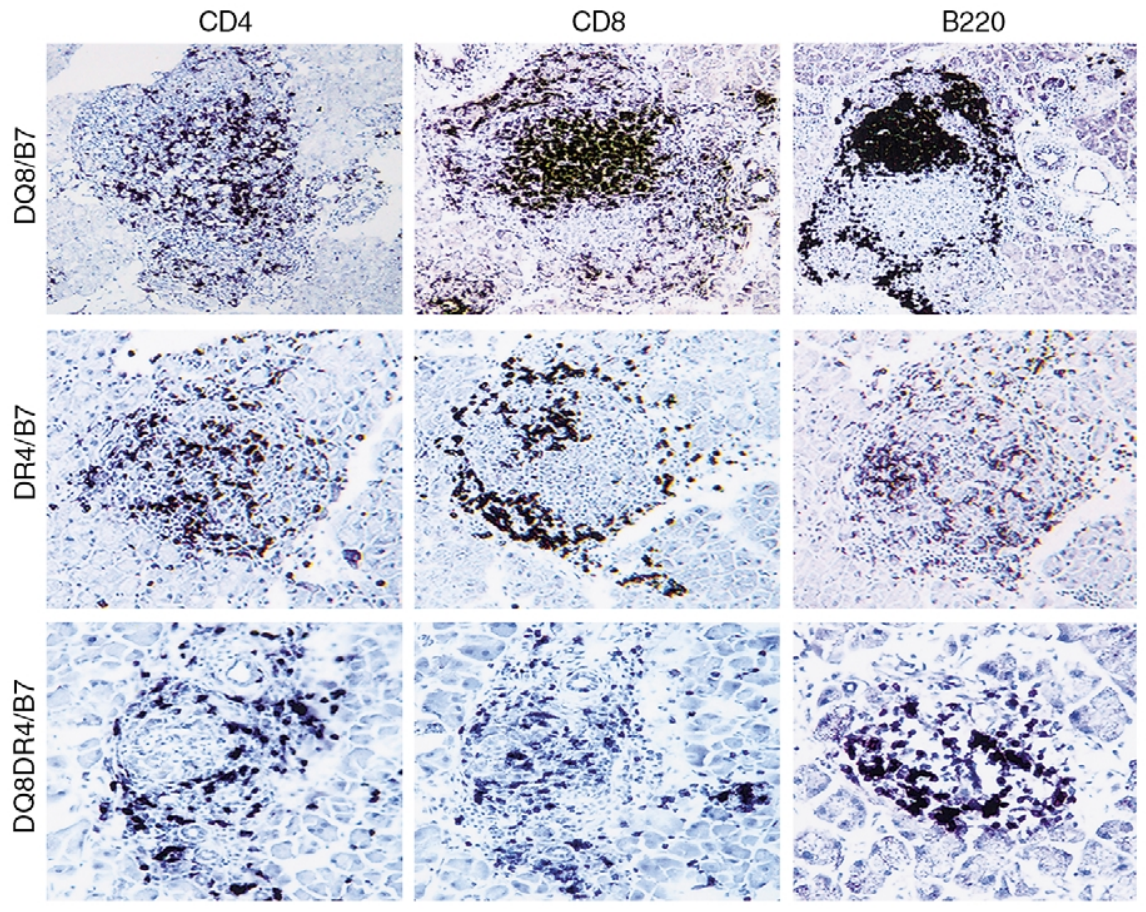

mice (like their $\mathrm{DQ}^{+} / \mathrm{mII}^{-}$counterparts) developed spontaneous insulitis or diabetes over a period of 10 months' observation (data not shown).

Incidence of spontaneous diabetes in $D R 4^{+} / \mathrm{mII} / / R I P-B 7.1$ and $D Q 8^{+} / \mathrm{mII}^{-} / \mathrm{RIP}$-B7.1 mice and in mice coexpressing DR4 and DQ8. The introduction of the RIP-B7.1 transgene into $\mathrm{DR}^{+} / \mathrm{mII}^{-}$mice caused the development of spontaneous diabetes in $25 \%$ (5 of 20 ) of DR $4^{+} / \mathrm{mII}^{-} / \mathrm{RIP}-\mathrm{B} 7.1$ mice. Like the $\mathrm{DQ}^{+} / \mathrm{mII}^{-} / \mathrm{RIP}-\mathrm{B} 7.1$ mice, there was no sex preference, and disease development occurred with similar kinetics in $\mathrm{DR} 4^{+} / \mathrm{mII}^{-} / \mathrm{RIP}-\mathrm{B} 7.1$ mice (Figure 2). However, the overall incidence of diabetes in $\mathrm{DR}^{+} / \mathrm{mII}^{-} / \mathrm{RIP}-\mathrm{B} 7.1$ mice was much lower than that found in $\mathrm{DQ}^{+} / \mathrm{mII}^{-} / \mathrm{RIP}-\mathrm{B} 7.1$ mice (Figure 2). The incidence of diabetes was threefold higher in the $\mathrm{DQ}^{+} / \mathrm{mII}^{-} / \mathrm{RIP}-\mathrm{B} 7.1$ mice $(73 \%$; 11 of 15 ) (Figure 2 ), which are values similar to those in our recent report (34). Of particular interest, when DR4 was introduced into $\mathrm{DQ}^{+} / \mathrm{mII}^{-} / \mathrm{RIP}-\mathrm{B} 7.1$ mice, the incidence of diabetes was markedly reduced to a level similar to that found in $\mathrm{DR}^{+} / \mathrm{mII}^{-} / \mathrm{RIP}-\mathrm{B} 7.1$ mice $(23 \% ; 5$ of 22 ) (Figure 2).

None of the murine MHC class II-sufficient mice $\left(\mathrm{DR}^{+} / \mathrm{mII}^{+} / \mathrm{RIP}-\mathrm{B} 7.1\right.$ or $\left.\mathrm{DQ}^{+} \mathrm{DR}^{+} / \mathrm{mII}^{+} / \mathrm{RIP}-\mathrm{B} 7.1\right)$ developed diabetes (data not shown). As in previous experiments, one of ten (10\%) of the mouse MHC class II-deficient RIP-B7.1 mice (mII-/RIP-B7.1) also developed diabetes (Figure 2).

Fewer $C D 8^{+}$T-cell infiltrates in pancreatic islets of $D R 4^{+} / \mathrm{mII}^{-} / \mathrm{RIP}-\mathrm{B} 7.1$ and $\mathrm{DQ} 8^{+} \mathrm{DR} 4^{+} / \mathrm{mII}^{-} / \mathrm{RIP}-\mathrm{B} 7.1 \mathrm{dia}-$ betic mice compared with diabetic $D Q 8^{+} / \mathrm{mII}^{-} / R I P-B 7.1$ mice. Pancreata from mice that developed diabetes were analyzed for lymphocytic infiltration by immunohistochemistry staining. Although the number of peripheral $\mathrm{CD}^{+} \mathrm{T}$ cells was very similar between $\mathrm{DQ}^{+} / \mathrm{mII}^{-} / \mathrm{RIP}-\mathrm{B} 7.1$ and $\mathrm{DR} 4^{+} / \mathrm{mII}^{-} / \mathrm{RIP}-$ B7.1 mice, it appeared that fewer $\mathrm{CD}^{+} \mathrm{T}$ cells were found in diabetic DR4 $4^{+} / \mathrm{mII}^{-} /$RIP-B7.1 islet infiltrates than were seen in diabetic $\mathrm{DQ}^{+} / \mathrm{mII}^{-} / \mathrm{RIP}-\mathrm{B} 7.1$ islet infiltrates (Figure 3). Fewer $\mathrm{CD}^{+} \mathrm{T}$-cell infiltrates were also seen in diabetic DQ8 ${ }^{+} \mathrm{DR} 4^{+} / \mathrm{mII}^{-} / \mathrm{RIP}-\mathrm{B} 7.1$ mice (Figure 3). However, in this case coexpression of DQ8 and DR4 led to better selection and maturation of $\mathrm{CD}^{+} \mathrm{T}$ cells (see above) on the murine MHC class II-deficient background; therefore, the ratio of CD4/CD8 in DQ8 ${ }^{+} \mathrm{DR}^{+} / \mathrm{mII}^{-} / \mathrm{RIP}-\mathrm{B} 7.1$ mice is relatively greater than that in $\mathrm{DQ}^{+} / \mathrm{mII}^{-} / \mathrm{RIP}-\mathrm{B} 7.1$ and $\mathrm{DR}^{+} / \mathrm{mII}^{-} / \mathrm{RIP}-\mathrm{B} 7.1$ mice.

Insulitis and/or diabetes could be transferred by diabetic splenocytes of DR $4^{+} / \mathrm{mII}^{-} / \mathrm{RIP}-\mathrm{B} 7.1$ or $D Q 8^{+} \mathrm{DR} 4^{+} / \mathrm{mII}^{-} / \mathrm{RIP}-$ $B 7.1$ mice. Because the expression of the RIP-B7.1 transgene is required for the adoptive transfer model in the RIP-B7.1 transgenic systems $(34,40,41)$, adoptive transfer recipients in this study were RIP-B7.1-transgene positive. We have shown that diabetic $\mathrm{DQ}^{+} / \mathrm{mII}^{-} / \mathrm{RIP}-\mathrm{B} 7.1$ splenoctyes can adoptively transfer diabetes to irradiated syngeneic recipients (34). In a similar manner, splenocytes (depleted of erythrocytes) from diabetic $\mathrm{DR}^{+} / \mathrm{mII}^{-} / \mathrm{RIP} . \mathrm{B} 7-1$ and $\mathrm{DQ}^{+}{ }^{+} \mathrm{DR}^{+} / \mathrm{mII}^{-} / \mathrm{RIP}^{-B} 7.1$ mice were adoptively transferred into sublethally irradiated DR4 ${ }^{+} / \mathrm{mII}^{-} / \mathrm{RIP} \mathrm{B} 7-1$ and DQ8 ${ }^{+} \mathrm{DR} 4^{+} / \mathrm{mII}^{-} / \mathrm{RIP}^{-}$ B7.1 mice, respectively. The experiments were terminated 8 weeks after adoptive transfer. Diabetes developed in $38 \%$ of the $\mathrm{DR}^{+} / \mathrm{mII}^{-} / \mathrm{RIP} . \mathrm{B} 7-1$ recipients (three of eight; 4, 6, and 6 weeks after transfer) that received $\mathrm{DR}^{+} / \mathrm{mII}^{-} / \mathrm{RIP} . \mathrm{B} 7-1$ diabetic splenocytes and in four of eight $(50 \% ; 4,5,6$, and 6 weeks after transfer) of $\mathrm{DQ}^{+} \mathrm{DR} 4^{+} / \mathrm{mII}^{-} / \mathrm{RIP}-\mathrm{B} 7.1$ recipients given diabetic DQ8 ${ }^{+} \mathrm{DR} 4^{+} / \mathrm{mII}^{-} / \mathrm{RIP}-\mathrm{B} 7.1$ splenocytes. 
Reconstitution of insulitis by nondiabetic $B M$ cells from $D Q 8^{+} / \mathrm{mII}^{-} / \mathrm{RIP}-\mathrm{B} 7.1, \quad \mathrm{DR} 4^{+} / \mathrm{mII} / \mathrm{RIP}-\mathrm{B7.1}$ and $\mathrm{DQ} 8^{+}$ $D R 4^{+} / \mathrm{mII} / R I P-B 7.1$ mice. To evaluate the role of BMderived human MHC class $\mathrm{II}^{+}$cells in disease development, we generated BM chimeras by transferring BM cells (after depletion of erythrocytes) from human MHC class $\mathrm{II}^{+} / \mathrm{RIP}-\mathrm{B} 7.1$ transgenic mice (8 to 12 weeks of age) into lethally irradiated human MHC class II-/RIP-B7.1 transgenic recipients ( 10 to 12 weeks of age, $n=3-5 /$ group). We aimed to study the prediabetic phase in these experiments and chose 8 weeks as the observation period. All the recipients except one (which received DQ8 ${ }^{+} \mathrm{DR} 4^{+} / \mathrm{mII}^{-} / \mathrm{RIP}-$ B7.1 BM cells), were diabetes free in the 8-week observation period. The reconstitution was successful and stable as determined by the expression of the appropriate human MHC class II molecules on $\mathrm{B}_{220^{+}}$cells in human MHC class II-negative recipients (Figure 4a) and by the positively selected mature $\mathrm{CD} 4$ or $\mathrm{CD} 8$ splenocytes (Figure 4a). However, when we analyzed the pancreata of the recipients, a different picture was revealed. Although insulitis was found in all the recipients, the severity of the insulitis was different: insulitis in the $\mathrm{DQ}^{+} / \mathrm{mII}^{-} / \mathrm{RIP}-\mathrm{B} 7.1$ and $\mathrm{DQ}^{+}{ }^{\mathrm{DR}} 4^{+} / \mathrm{mII}^{-} / \mathrm{RIP}-\mathrm{B} 7.1$ mice was similar and much greater than in $\mathrm{DR}^{+} / \mathrm{mII}^{-} / \mathrm{RIP}-\mathrm{B} 7.1$ (Figure 4b). It is interesting that the only recipient who developed diabetes at the time when the experiment was terminated exhibited infiltration in both islets and exocrine tissue (data not shown). The same cohort of the experiments was repeated using antiCD3-depleted BM cells, and very similar results were obtained. This indicates that the $T$ cells infiltrating the islets are more likely derived from BM stem cells rather than the $0.5-1 \%$ of $\mathrm{CD}^{+}$cells in the untreated BM. BM chimeras were also generated using $\mathrm{BM}$ derived from $\mathrm{mII}^{-} / \mathrm{RIP}-$ B7.1 or $\mathrm{DQ}^{+} / \mathrm{mII}^{-} / \mathrm{RIP}-\mathrm{B} 7.1$ mice as controls, and none of the chimeras in the control groups developed insulitis when the experiment was terminated (8 weeks, data not shown).

Spontaneous $G A D$ and insulin reactivity in $D Q 8^{+} D R 4^{+} / \mathrm{mII}^{-} / R I P-B 7.1$ mice. We have shown in our recent study that diabetic splenocytes from $\mathrm{DQ}^{+} / \mathrm{mII}^{-} /$RIP.B7-1 mice responded to islets and the putative autoantigens GAD and/or insulin (34). This reactivity was accompanied by the production of IFN- $\gamma$, but not IL-4 (34). To investigate whether the low incidence of spontaneous diabetes seen in $\mathrm{DQ}^{+}$ $\mathrm{DR}^{+} / \mathrm{mII}^{-} / \mathrm{RIP}-\mathrm{B} 7.1$ mice was due to the loss of this autoreactivity restricted to DQ8, we performed in vitro proliferation assays using purified $\mathrm{CD} 4^{+} \mathrm{T}$ cells from splenocytes of nondiabetic (Figure 5) and diabetic (data not shown) $\mathrm{DQ}^{+}{ }^{+} \mathrm{DR} 4^{+} / \mathrm{mII}^{-} / \mathrm{RIP}-\mathrm{B} 7.1$ mice. $\mathrm{CD}^{+} \mathrm{T}$ cells from $\mathrm{DR} 4^{+} / \mathrm{mII}^{-} / \mathrm{RIP}-\mathrm{B} 7.1$ mice showed moderate responses to GAD and insulin (1,400 and 1,260 cpm, respectively; over $470 \mathrm{cpm}$ in the absence of the Ag's), whereas $\mathrm{CD}^{+}$ $\mathrm{T}$ cells from $\mathrm{DQ}^{+} / \mathrm{mII}^{-} / \mathrm{RIP}-\mathrm{B} 7.1$ mice showed similar results (albeit a lower level as compared with diabetic individuals; data not shown) to our previous study (34). Introduction of DR4 into DQ8 ${ }^{+} / \mathrm{mII}^{-} / \mathrm{RIP} . \mathrm{B} 7-1$ mice (namely DQ8 ${ }^{+} \mathrm{DR} 4^{+} / \mathrm{mII}^{-} / \mathrm{RIP}-\mathrm{B} 7.1$ mice) did not abolish the islet autoantigen reactivity (Figure 5). Moreover, the responses were restricted to both DQ8 and DR4, as shown by $\mathrm{Ab}$-inhibition assay (Figure 5 , $\mathrm{a}$ and $\mathrm{b}$ ). The a
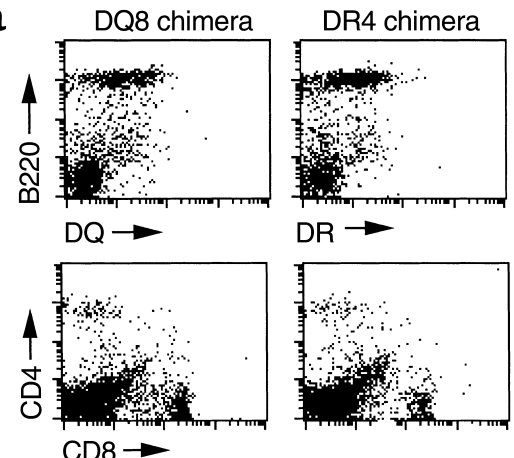

$\mathrm{DR} \rightarrow$
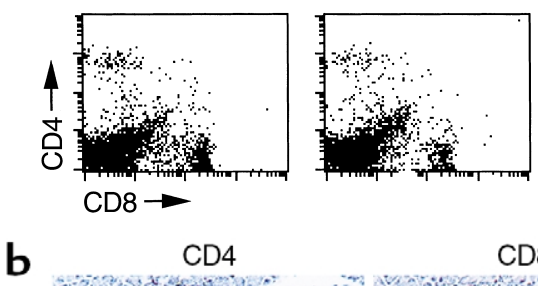

CD4
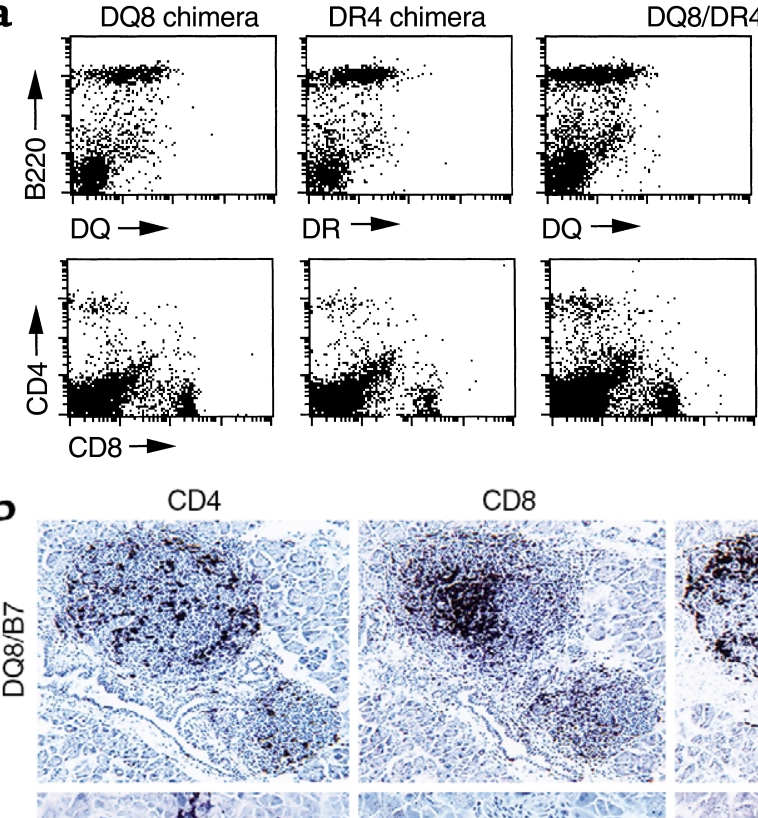

$\mathrm{DQ} \rightarrow$

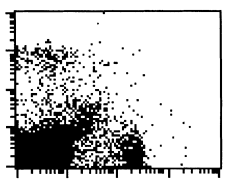

$\mathrm{CD} 8$
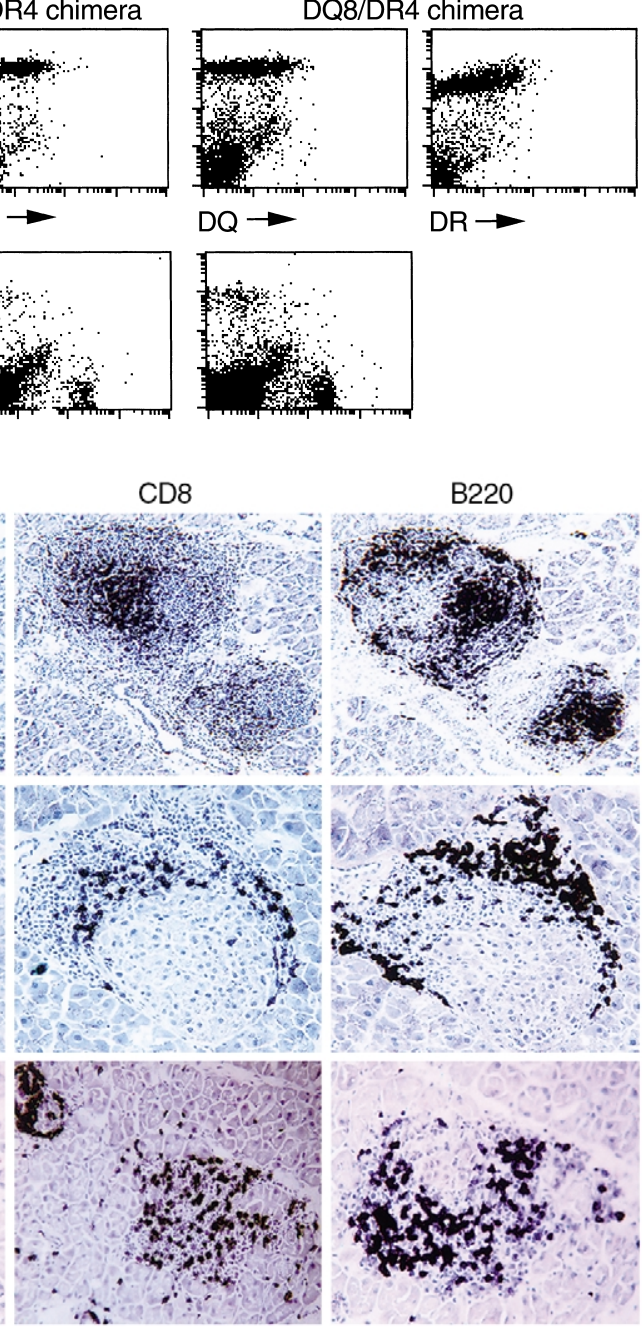

$\mathrm{DR} \rightarrow$
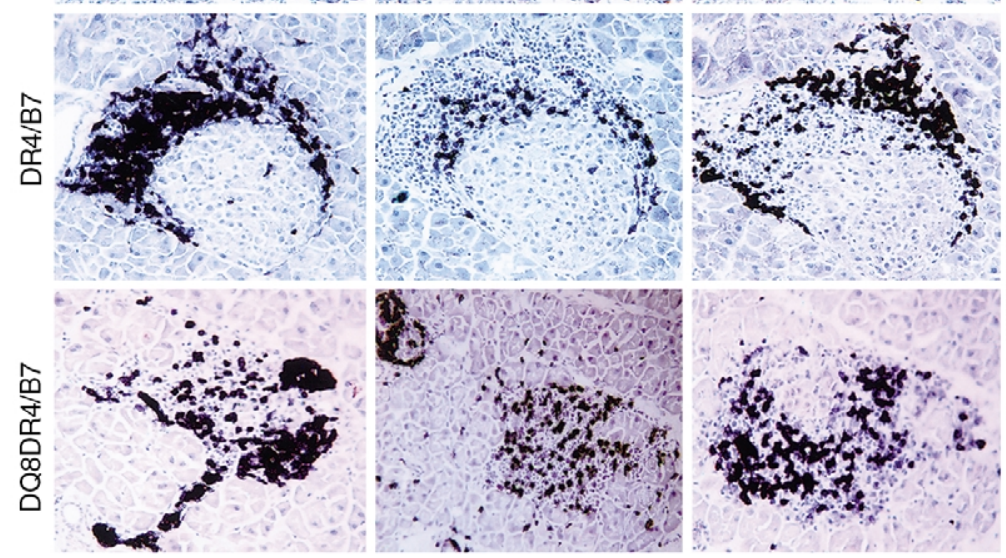

Figure 4

(a) Expression of HLA transgenes and the selection of CD4 ${ }^{+} \mathrm{T}$ cells in BM chimeras. In the top panel, lymphocytes isolated from the spleens of three types of chimeras (as indicated) were stained with the B-cell marker B220 (PE) in combination with either anti-HLA-DQ (FITC) or DR (FITC). In the lower panel, the same splenocytes were stained with anti-CD4 (PE) and anti-CD8 (FITC). (b) Immunohistochemistry staining of pancreatic sections of BM chimeras. In the upper panel are DQ $8^{+} / \mathrm{mII}^{-} / \mathrm{RIP}-\mathrm{B} 7$ $\mathrm{BM}$ chimera. DR4 $/ \mathrm{mll}^{-} / \mathrm{RIP}-\mathrm{B} 7 \mathrm{BM}$ chimera are in the middle panel. The lower panel shows DQ8+DR4 $/ \mathrm{mll}^{-} / \mathrm{RIP}-\mathrm{B} 7 \mathrm{BM}$ chimera. Islet infiltrates were stained for CD4 ${ }^{+}$ $\mathrm{T}$ cells (left), CD8 ${ }^{+} \mathrm{T}$ cells (middle), and B220+ $\mathrm{B}$ cells (right). 


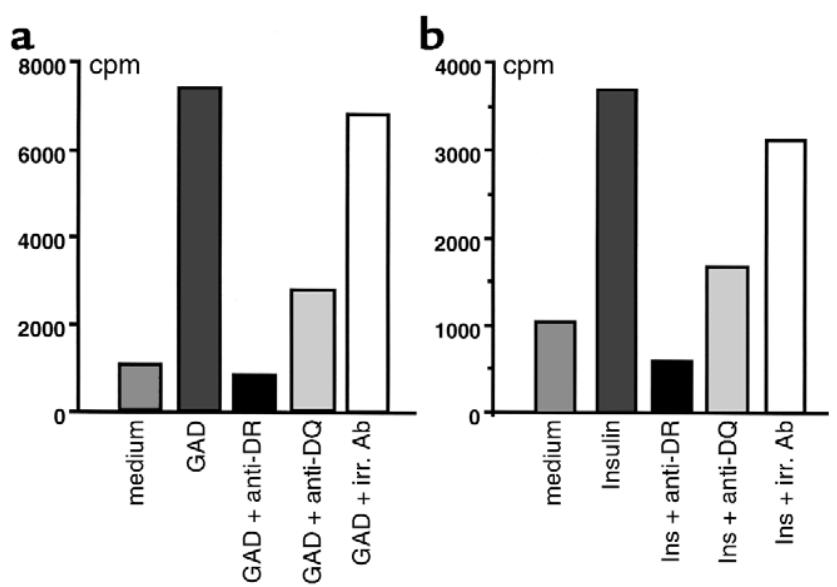

Figure 5

In vitro proliferation of T cells derived from diabetic spleens to islet $\beta$-cell autoantigens GAD and insulin (Ins). (a) Purified T cells $\left(2 \times 10^{5} /\right.$ well) were cultured in medium (Click's medium containing $5 \%$ heat-inactivated FCS) alone or with Ag's (as indicated) in the presence of irradiated (irr.) splenocytes as Ag-presenting cells. (b) HLA restriction of the proliferative response was also tested in the assays by addition of supernatants of mAb's to DR (HB55) and DQ (HB144). The irrelevant control $A b$ used in the assays was anti-I $A^{b}$ (Y3JP). The cultures were pulsed with $0.5 \mu \mathrm{Ci}^{3} \mathrm{H}$ after 72 hours.

blocking experiments were repeated on two further occasions with similar results (data not shown). However, the profile of cytokines produced by islet autoantigens in the mice expressing DQ8 and DR4 was different from that seen in $\mathrm{DQ}^{+} / \mathrm{mII}^{-} / \mathrm{RIP} . \mathrm{B} 7-1$ mice, namely the suppression of IFN- $\gamma$ and the production of IL4, albeit at low levels (Figure 6a).

We also studied another cohort of control $\mathrm{mII}^{-}$mice that express DQ8 or DR4 or both (DQ8DR4), but without the expression of RIP-B7 transgene. No CD4 ${ }^{+} \mathrm{T}$ cells from any of the groups showed notable proliferative responses to either GAD or insulin (data not shown), and cytokine production (IFN- $\gamma$ and IL-4) was only slightly above detection levels (Figure 6a). However, anti-CD3 stimulation drove the production of both IFN- $\gamma$ and IL- 4 by those $\mathrm{CD} 4^{+} \mathrm{T}$ cells (Figure $6 \mathrm{~b}$ ), and the profile of either IFN- $\gamma$ or IL- 4 was similar to that seen in mice expressing RIP-B7 transgene (Figure 6b).
All the experiments shown above were repeated using total $\mathrm{T}$ cells $\left(\mathrm{CD}^{+}\right.$and $\left.\mathrm{CD} 8^{+}\right)$, and very similar results were obtained (data not shown). This suggests that the effect of DR4 on a Th2-like immune response is confined to $\mathrm{CD} 4^{+} \mathrm{T}$ cells in these mice.

To identify the T-cell epitopes giving the spontaneous GAD response in $\mathrm{DQ}^{+}{ }^{+} \mathrm{DR} 4^{+} / \mathrm{mII}^{-} / \mathrm{RIP}-\mathrm{B} 7.1$ mice, we tested six GAD peptides (GAD 61-80, 201-220, 281-300, 247-266, 509-528, and 524-543). However, none of these peptides generated notable T-cell reactivity either in assays of proliferation or cytokine production. The antigenic peptide(s) recognized by $\mathrm{CD} 4^{+} \mathrm{T}$ cells remain to be determined. There were no spontaneous responses to IA-2, another well-characterized islet $\beta$-cell autoantigen.

Expression of DR 4 may cause CD4 T cells to differentiate toward a Th2 phenotype. To confirm the cytokine production in response to autoantigens, we stimulated the $\mathrm{CD}^{+}{ }^{+} \mathrm{T}$ cells from $\mathrm{DQ}^{+} / \mathrm{mII}^{-} / \mathrm{RIP}-\mathrm{B} 7.1, \mathrm{DR} 4^{+} / \mathrm{mII}^{-} / \mathrm{RIP}-$ B7.1, or DQ8 ${ }^{+} \mathrm{DR} 4^{+} / \mathrm{mII}^{-} / \mathrm{RIP}-\mathrm{B} 7.1$ mice with anti-CD3, which induces maximum stimulation of T cells. Supernatants were harvested after 48 hours and assayed for cytokine production (IFN- $\gamma$, IL-4, IL-6). As shown in Figure $6 \mathrm{~b}, \mathrm{CD}^{+} \mathrm{T}$ cells from $\mathrm{DQ}^{+} / \mathrm{mII}^{-} / \mathrm{RIP}-\mathrm{B} 7.1$ mice secreted a high level of IFN- $\gamma$ and a relatively low level of IL-4, whereas the expression of DR4 (either alone or together with DQ8) reversed this pattern of the cytokine production. The production of IL-6 could be detected, albeit at low level, in the supernatants of stimulated $\mathrm{CD}^{+} \mathrm{T}$ cells from mice expressing DR4 (either alone or together with DQ8), whereas it was undetectable in the supernatant of stimulated $\mathrm{CD}^{+} \mathrm{T}$ cells from $\mathrm{DQ}^{+} / \mathrm{mII}^{-} / \mathrm{RIP}-\mathrm{B} 7.1$ mice (data not shown).

Chemokines are chemotactic cytokines, and the interaction of chemokines and their receptors are important for both primary and secondary (memory) immune responses. It has been shown that certain chemokine receptors, such as CCR5, CXCR3, and CCR1, are preferentially expressed in Th1 cells (42-45). To investigate whether the downregulation of endogenous Th1 immune response by the expression of DR4 also affects chemokine-receptor expression, we examined the mRNA levels of CCR5 and CCR2 on anti-CD3-activated $\mathrm{CD}^{+} \mathrm{T}$ cells from $\mathrm{DQ} 8^{+} \mathrm{DR} 4^{+} / \mathrm{mII}^{-} / \mathrm{RIP}-\mathrm{B} 7.1$ and $\mathrm{DQ}^{+} / \mathrm{mII}^{-} / \mathrm{RIP}-\mathrm{B} 7.1$ mice. Although this is not a real-

\section{Figure 6}

Cytokine production by $\mathrm{CD} 4^{+} \mathrm{T}$ cells after GAD (a) and anti-CD3 (b) stimulation. Purified $\mathrm{CD}^{+}$cells $\left(2 \times 10^{6} / \mathrm{ml}\right)$ from spleens of nondiabetic mice, as indicated, were cultured with GAD protein or anti-CD3 (2C11 supernatant) in the presence of irradiated splenocytes for 72 and 48 hours, respectively. The culture supernatants were then tested for the production of IFN- $\gamma$ and IL-4 using ELISA. a

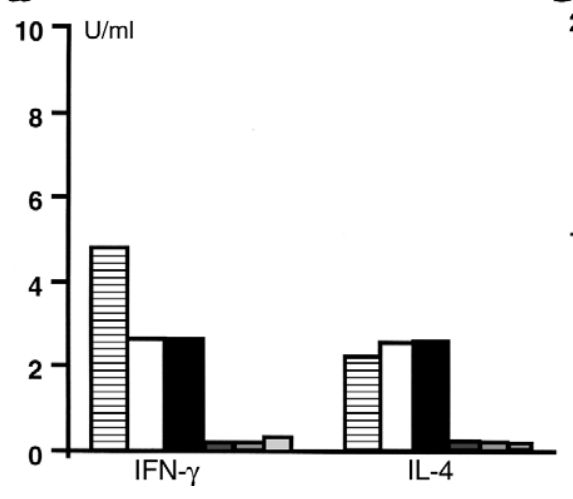

b

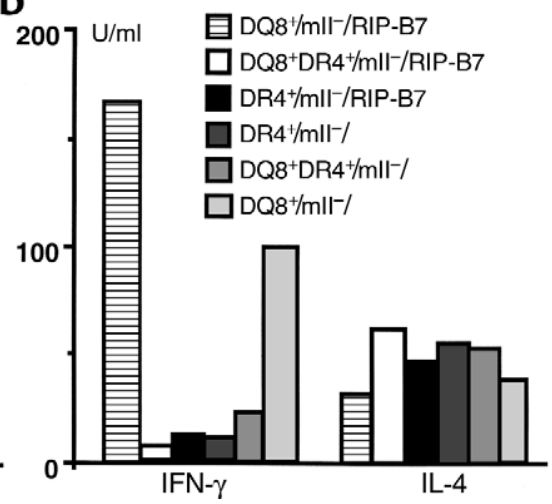




\section{Figure 7}

The mRNA expression of chemokines CCR5 and CCR2. Expression of chemokines CCR5 and CCR2 mRNA was assessed using RT-PCR (see Methods), as shown in the ethidium-bromide stained gel. CD3E was used as the internal control for the normalization of RNA levels of tested samples, as indicated. Lane 1: 100-bp ladder; lanes 2-5: CCR5 or CCR2, as shown. RT-PCR was performed on oligo-dT-synthesized cDNA, which was derived from total RNA of anti-CD3-stimulated T cells from spleens of nondiabetic mice as indicated.

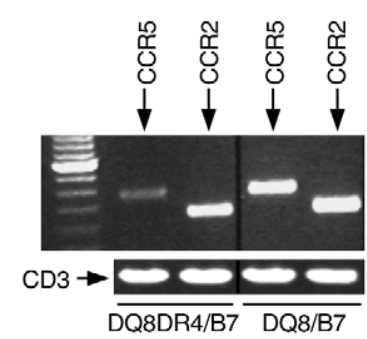

Microsatellite analysis of $D Q 8^{+} / \mathrm{mII}-/ R I P-B 7.1$, $D R 4^{+} / \mathrm{mII}^{-} / \mathrm{RIP}-\mathrm{B} 7.1$, and $D Q 8^{+} D R 4^{+} / \mathrm{mII}^{-} / \mathrm{RIP}-\mathrm{B} 7.1$ mice. We are aware that genetic background can influence immune responses, and to examine whether the mice used in the study were on the same genetic background (C57BL/6) we performed microsatellite analysis using 17 genetic markers that span mouse chromosomes 1 to $7,9,11,13$, and 14 (see Methods). The mapping results are identical at the loci for the C57BL/6 strain (Massachusetts Institute of Technology database) and do not support the possibility of some genes carried over with the expression of DR4, contributing to the disease modulation described above. However, it is clear that this does not cover the entire mouse genome.

\section{Discussion}

Studies examining MHC types associated with T1DM have identified individual loci associated with the disease, although haplotypes (an association of several genes together) are likely to be much more important in defining diabetes susceptibility or resistance. DR4 and/or DR3 have been shown to be strongly associated with T1DM in various types of studies (populations, families, and twins) (49-54). Among DR4 subtypes, DRB1*0401 has been reported to be most strongly associated with the disease (55). However, the strong linkage disequilibrium within the MHC involving DQ8 (DQA1*0301/DQB1*0302) and DR4 (DRB1*0401) makes it difficult to ascribe inde-
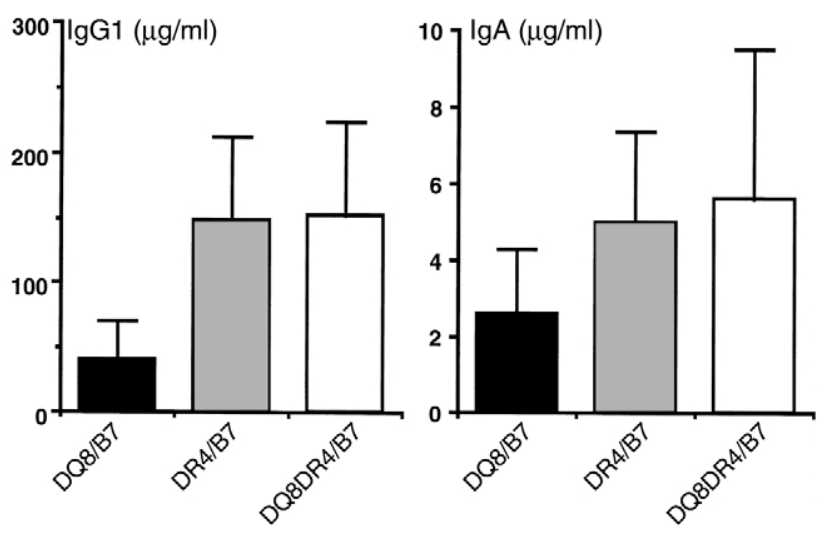

\section{Figure 8}

Expression of Ig isotypes in DQ8+/mII-/RIP-B7, DR4 $+\mathrm{mll}^{-} / \mathrm{RIP}-\mathrm{B} 7$, and DQ8 ${ }^{+} \mathrm{DR}^{+} / \mathrm{mll}^{-} / \mathrm{RIP}-\mathrm{B} 7$ mice. Serum levels of $\operatorname{lgG} 1$ and $\lg A$ were measured using ELISA (see Methods) in the three groups of mice as indicated. The number of mice in each group was 15, 20, and 22 for $\mathrm{DQ}^{+} / \mathrm{mll}^{-} / \mathrm{RIP}-\mathrm{B} 7, \mathrm{DR}^{+} / \mathrm{mll}^{-} / \mathrm{RIP}-\mathrm{B} 7$, and DQ8 ${ }^{+} \mathrm{DR} 4^{+} / \mathrm{mII}^{-} / \mathrm{RIP}-\mathrm{B} 7$ mice, respectively. The results are presented as mean \pm SD. Student's $t$ test was used for the statistical analysis. 
pendent associations with diabetes. It is noteworthy that TIDM patients more commonly express DR4 in combination with DR3 haplotypes than DR4 homozygotes. The findings of this study may suggest a reason why this is so in that DR4 may have an inhibitory effect on the susceptibility given by DQ8 and that in a homozygous state, the relative inhibitory effect of DR4 may override DQ8. In this study we have dissected the role of DR4 (DRB1*0401) independently or in association with DQ8 on the development of spontaneous diabetes by using HLA-transgenic mice. To our surprise, DR4, to a large extent, downregulated the strong diabetogenic effect of DQ8 when they were coexpressed, and the diabetogenic effect of DR4 alone was much milder than that of DQ8 in our spontaneous diabetes mouse model and only slightly greater than in mice not expressing MHC class II (25\% vs. $10 \%$ ). The data suggest that the inhibitory effect of DR 4 may be mediated by selection of islet $\beta$ cell-specific Th2 regulatory CD4 T cells or by preferential presentation of islet $\beta$ cell-associated self-proteins to the immune system in a manner that activates a protective Th2 type of CD4+ T cell response.

It has been reported by several groups that expression of an I-E transgene in NOD mice protects them from diabetes development (56-58). Although the mechanism of how the protection occurs has not been fully elucidated, deletion of self-reactive $T$ cells (clonal deletion) due to the expression of I-E molecules did not appear to be the cause. Hanson et al. (59) had shown that expression of E $\alpha^{d}$ transgene in NOD mice blocked diabetes development by altering the balance of cytokines produced by immunization with islet $\beta$ cell-associated autoantigen, directing autoreactive $T$ cells toward a Th2type immune response. Our data presented here are consistent with and extended those findings. In our model, expression of DR4 molecules altered the cytokine profile of spontaneous GAD and insulin autoreactivity. The change of serum Ig isotypes by the expression of DR4 provides further support for the Th2-like phenotype seen in these mice. It is conceivable that the expression of DR 4 may have altered general immune responses (not just limited to islet $\beta$ cell-associated autoreactive T cells) to Th2 type of responses because it is unlikely that the increased levels of IgG1 and IgA seen in DR4 ${ }^{+}$or $\mathrm{DQ}^{+} \mathrm{DR} 4^{+}$mice are all islet $\beta$ cell-associated autoantibodies. In fact, the results from the anti-CD 3 cross-linking experiments suggested a general Th2 immune response confined to $\mathrm{CD} 4^{+} \mathrm{T}$ cells in these mice.

It is interesting that fewer $\mathrm{CD}^{+} \mathrm{T}$ cells were found in diabetic $\mathrm{DR}^{+} / \mathrm{mII}^{-} / \mathrm{RIP}-\mathrm{B} 7.1$ islet infiltrates than were seen in diabetic $\mathrm{DQ}^{+} / \mathrm{mII}^{-} / \mathrm{RIP}-\mathrm{B} 7.1$ islet infiltrates, although the number of peripheral $\mathrm{CD}^{+} \mathrm{T}$ cells was very similar between these two types of mice. It is possible that the reduction of IFN- $\gamma$-producing Th1 immune responses due to the expression of DR4 may also diminish the recruitment and/or homing of diabetogenic $\mathrm{T}$ cells, including $\mathrm{CD} 8^{+} \mathrm{T}$ cells.

$\mathrm{CD}^{+} \mathrm{T}$ cells play an important role in regulating the functions of the immune system, and numerous stud- ies in both human and animals have shown the contribution of Th1 or Th2 to the pathogenesis of a wide variety of diseases (60-68). The dichotomy of Th1 and Th2 cells in the development of T1DM has also been well documented $(8-15,69)$. Most of the studies demonstrate that Th1 cells contribute to the immunopathogenesis of islet $\beta$-cell destruction, whereas Th 2 cells mediate disease protection. Based on these studies, new strategies in oral or nasal immunotherapy (which promote Th2 immune responses) for diabetes prevention have been tested in experimental animals (16-19), and some of the regimens are currently in clinical trials. More recently, Lyons et al. (70) demonstrated the influence of the idd 9 genetic interval on the pathogenesis of insulitis and diabetes in NOD mice. Using genomic-mapping analysis, the authors showed that the accumulation of IL-4-producing cells is associated with disease protection in the idd 9 loci. On the other hand, other studies have also shown that Th2 cells have the potential to be diabetogenic, as well (20-22). Thus, like most autoimmune disorders, the pathogenesis of T1DM cannot be explained simply by the dichotomy of Th1 and Th2, even though many studies, including our own, support this notion. Although control of autoimmune disease, such as diabetes, may be achieved by therapeutic interventions designed to enhance Th2 responses, the cure or the prevention of the disease possibly will require the combination of different strategies.

To identify the T-cell epitopes giving the spontaneous GAD response in $\mathrm{DQ}^{+} \mathrm{DR}^{+} / \mathrm{mII}^{-} / \mathrm{RIP}-\mathrm{B} 7.1$ mice, we tested six GAD peptides (GAD 61-80, 201-220, 281-300, 247-266, 509-528, and 524-543). However, none of these peptides generated notable $\mathrm{T}$-cell reactivity either in assays of proliferation or cytokine production. Using B10M/DR4-transgenic mice, the founder of our $\mathrm{DR}^{+} / \mathrm{mII}^{-} \mathrm{C} 57 \mathrm{BL} / 6$ mice, Wicker et al. have identified several strongly binding GAD peptides restricted to DR4 using binding assays and an immunization approach (35). Peptides 201-220 and 524-543 that we have tested were either the same as Wicker et al. reported (201-220) or in the vicinity of a strongly binding GAD peptide in Wicker et al.'s study (531-550). Peptide 509-528 used in this study is in the vicinity of two relatively weak binding peptides (501-520 and 511-530) in Wicker et al.'s study (35), but a similar peptide (511-525) showed potent immunogenicity in another study using a similar system (71). There are several possibilities that could explain the nonresponsiveness to those GAD peptides, especially the strong binding peptides. First, the development of tolerance to those strong binding selfpeptides may contribute to the nonresponsiveness; second, it is possible that the lack of peptide response was due to the low frequency of $\mathrm{T}$ cells reactive to any given GAD peptide tested in our study; and last, it is likely that different GAD epitopes may be generated by Agpresenting cells in an in vivo and unimmunized setting such as ours. Thus, DR4 molecules may present preferentially these GAD peptides leading to a Th2 type of 
immune response. It is also possible that subdominant antigenic peptides or a determinant(s) generated during Ag spreading, which has been well documented in T1DM, may also induce protective, rather than pathogenic, immune responses $(10,72,73)$.

The present study provides both in vivo and in vitro evidence for a possible inhibitory role of DR4 in the development of diabetes. Our data as a whole are most consistent with the view that expression of DR4 enhances more endogenous Th2 type of immune responses. The precise mechanism of how DR4 molecules promote Th2 regulatory immune responses is currently under investigation. However, we believe that the idea that expression of DR4 promotes more endogenous Th2 type of immune responses may not be the only mechanism for disease modulation seen in our study. Regardless of what mechanisms are involved, our "humanized" spontaneous diabetes model provides us not only a novel means to study the immunopathological effect of individual genes in strong linkage disequilibrium that is impossible to dissect in humans, but will also provide novel information regarding the role of DR4 in disease development. This information is important for the development of effective immunotherapy, especially as we are studying the effect of DQ8/DR4 HLA genes - those commonly found in diabetic patients.

\section{Acknowledgments}

We thank Linda Wicker and Dennis Zaller for kindly providing us with original DR4 breeders; C.A. Janeway for his generosity; Joanne Appicelli for taking care of the animals used in this study. L. Wen is a current recipient and F.S. Wong is a past recipient of the Career Development Award from Juvenile Diabetes Foundation International. F.S. Wong is currently a Wellcome Trust Senior Fellow in Clinical Science. This work was supported by a NIH grant (AI-44427), a Diabetes Program Project Grant (DK-53015), and the islet core of Yale Diabetes Endocrinology Research Center (DERC).

1. Davies, J.L., et al. 1994. A genome-wide search for human type 1 diabetes susceptibility genes. Nature. 371:130-136.

2. Tisch, R., and McDevitt, H. 1996. Insulin-dependent diabetes mellitus. Cell. 85:291-297.

3. Todd, J.A., and Farrall, M. 1996. Panning for gold: genome-wide scanning for linkage in type 1 diabetes. Hum. Mol. Genet. 5:1443-1448.

4. Bendelac, A., Carnaud, C., Boitard, C., and Bach, J.F. 1987. Syngeneic transfer of autoimmune diabetes from diabetic NOD mice to healthy neonates. Requirement for both L3T4+ and Lyt-2+ T cells. J. Exp. Med. 166:823-832.

5. Miller, B.J., Appel, M.C., O’Neil, J.J., and Wicker, L.S. 1988. Both the Lyt$2+$ and L3T4+ T cell subsets are required for the transfer of diabetes in nonobese diabetic mice. J. Immunol. 140:52-58.

6. Wicker, L.S., et al. 1994. Beta 2-microglobulin-deficient NOD mice do not develop insulitis or diabetes. Diabetes. 43:500-504.

7. Serreze, D.V., Leiter, E.H., Christianson, G.J., Greiner, D., and Roopenian, D.C. 1994. Major histocompatibility complex class I-deficient NODB2mnull mice are diabetes and insulitis resistant. Diabetes. 43:505-509.

8. Mueller, R., Krahl, T., and Sarvetnick, N. 1996. Pancreatic expression of interleukin-4 abrogates insulitis and autoimmune diabetes in nonobese diabetic (NOD) mice. J. Exp. Med. 184:1093-1099.

9. Cameron, M.J., et al. 1997. IL-4 prevents insulitis and insulin-dependent diabetes mellitus in nonobese diabetic mice by potentiation of regulatory T helper-2 cell function. J. Immunol. 159:4686-4692.

10. Tian, J., Lehmann, P.V., and Kaufman, D.L. 1997. Determinant spread- ing of T helper cell 2 (Th2) responses to pancreatic islet autoantigens. J. Exp. Med. 186:2039-2043.

11. Rapoport, M.J., et al. 1998. Decreased secretion of Th2 cytokines precedes Up-regulated and delayed secretion of Th1 cytokines in activated peripheral blood mononuclear cells from patients with insulin-dependent diabetes mellitus. J. Autoimmun. 11:635-642.

12. Bradley, L.M., et al. 1999. Islet-specific Th1, but not Th2, cells secrete multiple chemokines and promote rapid induction of autoimmune diabetes. J. Immunol. 162:2511-2520.

13. Petersen, J.S., Kulmala, P., Clausen, J.T., Knip, M., and Dyrberg, T. 1999. Progression to type 1 diabetes is associated with a change in the immunoglobulin isotype profile of autoantibodies to glutamic acid decarboxylase (GAD65). Childhood Diabetes in Finland Study Group. Clin. Immunol. 90:276-281.

14. Gallichan, W.S., Balasa, B., Davies, J.D., and Sarvetnick, N. 1999. Pancreatic IL-4 expression results in islet-reactive Th2 cells that inhibit diabetogenic lymphocytes in the nonobese diabetic mouse. J. Immunol. 163:1696-1703.

15. Holz, A., et al. 1999. Disruption of the STAT4 signaling pathway protects from autoimmune diabetes while retaining antiviral immune competence. J. Immunol. 163:5374-5382.

16. Weiner, H.L., et al. 1994. Oral tolerance: immunologic mechanisms and treatment of animal and human organ-specific autoimmune diseases by oral administration of autoantigens. Annu. Rev. Immunol. 12:809-837.

17. Polanski, M., Melican, N.S., Zhang, J., and Weiner, H.L. 1997. Oral administration of the immunodominant B-chain of insulin reduces diabetes in a co-transfer model of diabetes in the NOD mouse and is associated with a switch from Th1 to Th2 cytokines. J. Autoimmun. 10:339-346.

18. Tian, J., et al. 1996. Nasal administration of glutamate decarboxylase (GAD65) peptides induces Th2 responses and prevents murine insulindependent diabetes. J. Exp. Med. 183:1561-1567.

19. Maron, R., Melican, N.S., and Weiner, H.L. 1999. Regulatory Th2-type T cell lines against insulin and GAD peptides derived from orally- and nasally-treated NOD mice suppress diabetes. J. Autoimmun. 12:251-258.

20. Katz, J.D., Benoist, C., and Mathis, D. 1995. T helper cell subsets in insulin-dependent diabetes. Science. 268:1185-1188.

21. Pakala, S.V., Kurrer, M.O., and Katz, J.D. 1997. T helper 2 (Th2) T cells induce acute pancreatitis and diabetes in immune-compromised nonobese diabetic (NOD) mice. J. Exp. Med. 186:299-306.

22. Poulin, M., and Haskins, K. 2000. Induction of diabetes in nonobese diabetic mice by Th2 $\mathrm{T}$ cell clones from a TCR transgenic mouse. J. Immunol. 164:3072-3078.

23. Suri-Payer, E., Amar, A.Z., Thornton, A.M., and Shevach, E.M. 1998. $\mathrm{CD} 4+\mathrm{CD} 25+\mathrm{T}$ cells inhibit both the induction and effector function of autoreactive $\mathrm{T}$ cells and represent a unique lineage of immunoregulatory cells. J. Immunol. 160:1212-1218.

24. Salomon, B., et al. 2000. B7/CD28 costimulation is essential for the homeostasis of the CD4+CD25+ immunoregulatory $\mathrm{T}$ cells that control autoimmune diabetes. Immunity. 12:431-440.

25. Nepom, B.S., Schwarz, D., Palmer, J.P., and Nepom, G.T. 1987. Transcomplementation of HLA genes in IDDM. HLA-DQ alpha- and beta-chains produce hybrid molecules in DR3/4 heterozygotes. Diabetes. 36:114-117.

26. Todd, J.A. 1990. The role of MHC class II genes in susceptibility to insulin-dependent diabetes mellitus. Curr. Top. Microbiol. Immunol. 164:17-40.

27. Khalil, I., et al. 1990. A combination of HLA-DQ beta Asp57-negative and HLA DQ alpha Arg52 confers susceptibility to insulin-dependent diabetes mellitus. J. Clin. Invest. 85:1315-1319.

28. Tosi, G., et al. 1994. The complex interplay of the DQB1 and DQA1 loci in the generation of the susceptible and protective phenotype for insulin-dependent diabetes mellitus. Mol. Immunol. 31:429-437.

29. Raju, R., Munn, S.R., and David, C.S. 1997. T cell recognition of human pre-proinsulin peptides depends on the polymorphism at HLA DQ locus: a study using HLA DQ8 and DQ6 transgenic mice. Hum. Immunol. 58:21-29.

30. Wen, L., et al. 1998. Induction of insulitis by glutamic acid decarboxylase peptide-specific and HLA-DQ8-restricted CD4(+) T cells from human DQ transgenic mice. J. Clin. Invest. 102:947-957.

31. Sonderstrup, G., and McDevitt, H. 1998. Identification of autoantigen epitopes in MHC class II transgenic mice. Immunol. Rev. 164:129-138.

32. Liu, J., Purdy, L.E., Rabinovitch, S., Jevnikar, A.M., and Elliott, J.F. 1999. Major DQ8-restricted T-cell epitopes for human GAD65 mapped using human CD4, DQA1*0301, DQB1*0302 transgenic IA(null) NOD mice. Diabetes. 48:469-477.

33. Guerder, S., Picarella, D.E., Linsley, P.S., and Flavell, R.A. 1994 Costimulator B7-1 confers antigen-presenting-cell function to parenchymal tissue and in conjunction with tumor necrosis factor alpha leads to autoimmunity in transgenic mice. Proc. Natl. Acad. Sci. USA. 91:5138-5142.

34. Wen, L., et al. 2000. In vivo evidence for the contribution of human his- 
tocompatibility leukocyte antigen (HLA)-DQ molecules to the development of diabetes. J. Exp. Med. 191:97-104.

35. Wicker, L.S., et al. 1996. Naturally processed T cell epitopes from human glutamic acid decarboxylase identified using mice transgenic for the type 1 diabetes-associated human MHC class II allele, DRB1*0401. J. Clin. Invest. 98:2597-2603.

36. Mora, C., Wong, F.S., Chang, C.H., and Flavell, R.A. 1999. Pancreatic infiltration but not diabetes occurs in the relative absence of MHC class II-restricted CD4 T cells: studies using NOD/CIITA-deficient mice. J. Immunol. 162:4576-4588.

37. Gonzalez, A., et al. 1997. Genetic control of diabetes progression. Immunity. 7:873-883.

38. Wen, L., et al. 1996. Germinal center formation, immunoglobulin class switching, and autoantibody production driven by "non alpha/beta" $\mathrm{T}$ cells. J. Exp. Med. 183:2271-2282.

39. Wong, S., et al. 1995. Expression of the co-stimulator molecule B7-1 in pancreatic beta-cells accelerates diabetes in the NOD mouse. Diabetes. 44:326-329.

40. Wong, F.S., et al. 1998. The role of lymphocyte subsets in accelerated diabetes in nonobese diabetic-rat insulin promoter-B7-1 (NOD-RIP-B7-1) mice. J. Exp. Med. 187:1985-1993.

41. Allison, J., et al. 1998. The threshold for autoimmune T cell killing is influenced by B7-1. Eur. J. Immunol. 28:949-960.

42. Bonecchi, R., et al. 1998. Differential expression of chemokine receptors and chemotactic responsiveness of type $1 \mathrm{~T}$ helper cells (Th1s) and Th2s. J. Exp. Med. 187:129-134.

43. Loetscher, P., et al. 1998. CCR5 is characteristic of Th1 lymphocytes. Nature. 391:344-345.

44. Patterson, B.K., et al. 1999. Regulation of CCR5 and CXCR4 expression by type 1 and type 2 cytokines: CCR5 expression is downregulated by IL10 in CD4-positive lymphocytes. Clin. Immunol. 91:254-262.

45. Cameron, M.J., et al. 2000. Differential expression of CC chemokines and the CCR5 receptor in the pancreas is associated with progression to type I diabetes. J. Immunol. 165:1102-1110.

46. Martin, R.M., and Lew, A.M. 1998. Is IgG2a a good Th1 marker in mice? Immunol. Today. 19:49.

47. Martin, R.M., Silva, A., and Lew, A.M. 1997. The Igh-1 sequence of the non-obese diabetic (NOD) mouse assigns it to the $\operatorname{IgG} 2 \mathrm{c}$ isotype. Immunogenetics. 46:167-168.

48. Martin, R.M., Brady, J.L., and Lew, A.M. 1998. The need for IgG2c specific antiserum when isotyping antibodies from C57BL/6 and NOD mice. J. Immunol. Methods. 212:187-192.

49. Rotter, J.I., et al. 1983. HLA genotypic study of insulin-dependent diabetes the excess of DR3/DR4 heterozygotes allows rejection of the recessive hypothesis. Diabetes. 32:169-174.

50. Wolf, E., Spencer, K.M., and Cudworth, A.G. 1983. The genetic susceptibility to type 1 (insulin-dependent) diabetes: analysis of the HLA-DR association. Diabetologia. 24:224-230.

51. Anderson, C.E., et al. 1983. A search for heterogeneity in insulin dependent diabetes mellitus (IDDM): HLA and autoimmune studies in simplex, multiplex and multigenerational families. Metabolism. 32:471-477.

52. Johnston, C., Pyke, D.A., Cudworth, A.G., and Wolf, E. 1983. HLA-DR typing in identical twins with insulin-dependent diabetes: difference between concordant and discordant pairs. Br. Med. J. (Clin. Res. Ed.) 286:253-255.

53. Srikanta, S., et al. 1983. Type I diabetes mellitus in monozygotic twins: chronic progressive beta cell dysfunction. Ann. Intern. Med. 99:320-326

54. Olmos, P., et al. 1988. The significance of the concordance rate for type 1 (insulin-dependent) diabetes in identical twins. Diabetologia. 31:747-750.
55. Sheehy, M.J. 1992. HLA and insulin-dependent diabetes. A protective perspective. Diabetes. 41:123-129.

56. Bohme, J., Schuhbaur, B., Kanagawa, O., Benoist, C., and Mathis, D. 1990. MHC-linked protection from diabetes dissociated from clonal deletion of T cells. Science. 249:293-295.

57. Lund, T., et al. 1990. Prevention of insulin-dependent diabetes mellitus in non-obese diabetic mice by transgenes encoding modified I-A betachain or normal I-E alpha-chain. Nature. 345:727-729.

58. Podolin, P.L., et al. 1993. I-E+ nonobese diabetic mice develop insulitis and diabetes. J. Exp. Med. 178:793-803.

59. Hanson, M.S., et al. 1996. Quantitative thresholds of MHC class II I-E expressed on hemopoietically derived antigen-presenting cells in transgenic NOD/Lt mice determine level of diabetes resistance and indicate mechanism of protection. J. Immunol. 157:1279-1287.

60. Reiner, S.L., Wang, Z.E., Hatam, F., Scott, P., and Locksley, R.M. 1993 $\mathrm{TH} 1$ and TH2 cell antigen receptors in experimental leishmaniasis. Science. 259:1457-1460.

61. Hoft, D.F., Schnapp, A.R., Eickhoff, C.S., and Roodman, S.T. 2000 Involvement of CD4(+) Th1 cells in systemic immunity protective against primary and secondary challenges with Trypanosoma cruzi. Infect. Immun. 68:197-204.

62. Maloy, K.J., et al. 2000. CD4(+) T cell subsets during virus infection. Protective capacity depends on effector cytokine secretion and on migratory capability. J. Exp. Med. 191:2159-2170.

63. Song, K., Chang, Y., and Prud'homme, G.J. 2000. Regulation of T-helper1 versus T-helper- 2 activity and enhancement of tumor immunity by combined DNA-based vaccination and nonviral cytokine gene transfer. Gene Ther. 7:481-492.

64. Faust, A., Rothe, H., Schade, U., Lampeter, E., and Kolb, H. 1996. Primary nonfunction of islet grafts in autoimmune diabetic nonobese diabetic mice is prevented by treatment with interleukin- 4 and interleukin- 10 . Transplantation. 62:648-652.

65. Zhai, Y., Ghobrial, R.M., Busuttil, R.W., and Kupiec-Weglinski, J.W. 1999 Th1 and Th2 cytokines in organ transplantation: paradigm lost? Crit. Rev. Immunol. 19:155-172.

66. Liblau, R.S., Singer, S.M., and McDevitt, H.O. 1995. Th1 and Th2 CD4+ $\mathrm{T}$ cells in the pathogenesis of organ-specific autoimmune diseases. Immunol. Today. 16:34-38.

67. Takahashi, S., et al. 1996. Imbalance towards Th1 predominance is associated with acceleration of lupus-like autoimmune syndrome in MRL mice. J. Clin. Invest. 97:1597-1604.

68. Singh, V.K., Mehrotra, S., and Agarwal, S.S. 1999. The paradigm of Th1 and Th2 cytokines: its relevance to autoimmunity and allergy. Immunol. Res. 20:147-161

69. Trembleau, S., Penna, G., Gregori, S., Gately, M.K., and Adorini, L. 1997. Deviation of pancreas-infiltrating cells to Th2 by interleukin-12 antagonist administration inhibits autoimmune diabetes. Eur. J. Immunol. 27:2330-2339.

70. Lyons, P.A., et al. 2000. The NOD Idd9 genetic interval influences the pathogenicity of insulitis and contains molecular variants of $\mathrm{Cd} 30$ Tnfr2, and Cd137. Immunity. 13:107-115.

71. Patel, S.D., et al. 1997. Identification of immunodominant T cell epitopes of human glutamic acid decarboxylase 65 by using HLADR(alpha $1 * 0101$,beta $\left.{ }^{*} 0401\right)$ transgenic mice. Proc. Natl. Acad. Sci. USA. 94:8082-8087.

72. Deng, H., et al. 1993. Determinant capture as a possible mechanism of protection afforded by major histocompatibility complex class II molecules in autoimmune disease. J. Exp. Med. 178:1675-1680.

73. Sercarz, E.E., et al. 1993. Dominance and crypticity of T cell antigenic determinants. Annu. Rev. Immunol. 11:729-766. 